\title{
Kajian Kebutuhan Peningkatan Kompetensi Mengajar Guru
}

\author{
Mahdiansyah \\ Puslitjaknov, Balitbang Kemdiknas, e-mail: mahdiansyah2007@gmail.com
}

\begin{abstract}
Abstrak. Tujuan studi ini adalah untuk mengidentifikasi kondisi obyektif kebutuhan sekolah, yang dapat dijadikan dasar dalam menentukan intervensi kebijakan melalui perencanaan program pendidikan. Secara khusus studi ini dimaksudkan untuk mengetahui: (a) karakteristik guru yang dipandang sebagai determinan kualitas guru, dan (b) kualitas guru yang difokuskan pada kompetensi guru dalam proses belajar mengajar dan identifikasi kebutuhan pelatihannya. Hasil studi menunjukkan bahwa latar belakang guru banyak yang tidak sesuai dengan mata pelajaran yang diajarkan (mismatch), terutama guru SMP/MTs dan SMA/ SMK/MA yang berasal dari sekolah swasta. Penguasaan guru SD/MI terhadap materi pelajaran yang menjadi tanggung jawabnya masih memprihatinkan. Namun, guru SMP/MTs dan SMA/SMK/MA sudah menguasai sebagian besar materi mata pelajaran. Upaya untuk meningkatkan profesionalisme guru dilakukan melalui kegiatan pelatihan, meskipun lebih dari dua perlima guru tidak pernah mengikuti penataran/pelatihan. Pelatihan tentang pengembagan kurikulum dan penyusunan tes dibutuhkan hampir oleh semua guru, terutama guru MI, MTs dan MA serta guru yang berlatar belakang pendidikan nonkeguruan.
\end{abstract}

Kata kunci: Kompetensi mengajar, kebutuhan peningkatan mutu guru

\begin{abstract}
This study aims to identify the objective read of the school needs objectively which can be taken into account in determining policy intervention through educational planning. The specific aims of the study are to obtain information on: a) teacher characteristics perceived as determinants of teacher quality b) teacher quality which focuses on their competence in teaching and learning process and need assessment of teacher training. Findings of the study show that there are many teachers whose educational backgrounds did not match with the subject they teach (mismatch). This is especially true in the case of private junior and senior secondary school teachers. There was a concern on the mastery of primary school teachers in the subjects they teach. At the junior and senior secondary levels most of the teachers had the mastery in most parts of the subjects they teach. Attempts to improve teacher professionalism were conducted through training. However, more than two fifth of teachers did not participate in any training. Training on how to develop curriculum and tests were needed by most of Islamic primary, junior secondary and senior secondary teachers who had non-teaching qualification background.
\end{abstract}

Key words: teaching competence, teacher quality improvement

\section{Pendahuluan}

Efektivitas dalam intervensi kebijakan pendidikan ditentukan oleh akurasi data empirik yang mendasari penentuan komponen intervensi. Di bidang pendidikan intervensi dikategorikan pada intervensi jangka pendek dan intervensi jangka panjang. Intervensi jangka pendek pada dasarnya diarahkan perbaikan tenaga pendidik dan pendidik, penyediaan sarana dan prasarana pendidikan di tingkat sekolah, dan perningkatan motivasi siswa, serta pembenahan pengelolaan pro-gram pendidikan baik di tingkat sekolah maupun pada organisasi pengelola pendidikan dari tingkat pusat sampai dengan kabupaten/kota bahkan kecamatan. Di lain pihak, intervensi jangka panjang cenderung diarahkan pada perbaikan status ekonomi orang tua dan perbaikan in-frastruktur sosial.

Baik intervensi jangka pendek maupun intervensi jangka panjang diarahkan untuk meningkatkan kualitas pelayanan pendidikan di tingkat sekolah. Indikator dari peningkatan kualitas bukan pada pengelolaan program pendidikan yang baik dan bukan juga pada peningkatkan kesejahteraan tenaga kependidikan dan pendidik di tingkat sekolah. Indikator ke- 
berhasilan intervensi adalah prestasi belajar dan kompetensi siswa.

Untuk mencapai hasil dalam waktu dekat, intervensi jangka pendek dianggap lebih layak (feasible). Hal ini didasarkan pada dua pertimbangan. Pertama pemerintah tidak mempunyai dana yang mencukupi untuk membiayai semua program pendidikan, meskipun program tersebut telah menjadi agenda kebijakan. Oleh karena itu, Pemerintah perlu untuk menentukan skala prioritas dengan berbagai pertimbangan. Kedua, Pemerintah cenderung ingin segera mengetahui dampak atau hasil dari intervensi.

Intervensi pemerintah untuk meningkatkan mutu pendidikan sebagai output pendidikan merupakan salah satu masalah "serius" yang dihadapi pemerintah, pemerintah daerah, dan bahkan sekolah. Hal ini dikarenakan mutu pendidikan merupakan cerminan kinerja pengelola pendidikan. Artinya, mutu pendidikan yang dicapai suatu daerah menggambarkan keberhasilan pekerja pendidikan dalam mengelola pendidikan.

Kota Bontang sebagai salah satu kota/ kabupaten di propinsi Kalimantan Timur tidak luput dari permasalahan mutu pendidikan. Keberadaan mutu pendidikan yang dicapai terkait dengan kondisi guru yang ada, seperti kondisi kualifikasi dan kompetensi guru. Hal ini beralasan karena guru merupakan unsur yang sangat penting dalam penciptaan kualitas pembelajaran di kelas dan sekolah. Oleh karena itu, kualifikasi pendidikan guru harus menjadi unsur penting dalam peningkatan kualitas pendidikan di Kota Bontang. Namun, sampai kini kualifikasi pendidikan guru masih belum sepenuhnya mencapai jenjang S1/D4, seperti yang dipersyaratkan dalam UURI No.14 Tahun 2005 Tentang Guru dan Dosen. Data Dinas Pendidikan dan Kebudayaan Kota Bontang menginformasikan bahwa sampai tahun 2007 masih terdapat 795 guru SD/SMP/SMA/SMK/ sederajat yang belum mencapai jenjang pendidikan tersebut. Sementara itu kompetensi guru sebagaimana dimaksud dalam pasal 8 Undang-Undang tersebut belum diketahui secara pasti.

Dalam mengantisipasi tantangan ke depan menuju kondisi yang diinginkan, Pemerintah Kota Bontang perlu secara terus menerus mengembangkan peluang dan inovasi baru. Perubahan tersebut harus disusun dalam tahapan yang terencana, konsisten dan berkelanjutan sehingga dapat meningkatkan akuntabilitas kinerja yang berorientasi pada pencapaian hasil atau manfaat. Berangkat dari fenomena tersebut, kajian terhadap kompetensi guru menarik untuk ditelaah. Berdasarkan isu yang diuraikan pada latar belakang, permasalahan studi ini dapat dirumuskan sebagai berikut: Bagaimanakah kondisi kompetensi mengajar guru di berbagai satuan pendidikan di kota Bontang?

Secara umum tujuan kajian ini dimaksudkan untuk mengidentifikasi kondisi obyektif kebutuhan sekolah, yang dapat dijadikan dasar dalam menentukan intervensi kebijakan melalui perencanaan program pendidikan. Prioritas penelitian ditujukan untuk mengevaluasi proses pendidikan di sekolah yang dicerminkan oleh kompetensi mengajar guru. Adapun tujuan khusus pelaksanaan kajian adalah untuk mengetahui: a) karakteristik guru yang dipandang sebagai determinan kualitas guru, dan b) kualitas guru yang difokuskan pada kompetensi guru dalam proses belajar mengajar dan identifikasi kebutuhan pelatihannya.

\section{Kajian Literatur}

Dalam upaya pembangunan pendidikan nasional, sangat diperlukan guru dalam jumlah yang memadai dan standar mutu kompetensi dan profesionalisme yang terjamin. Untuk mencapai jumlah guru profesional yang mencukupi yang dapat menggerakkan dinamika kemajuan pendidikan nasional diperlukan suatu proses yang menerus, tepat sasaran dan efektif. Proses menuju guru profesional ini perlu didukung oleh semua unsur yang terkait dengan guru. Unsurunsur tersebut dapat dipadukan untuk menghasilkan suatu sistem yang dapat dengan sendirinya bekerja menuju pembentukan guruguru yang profesional dalam kualitas maupun kuantitas yang mencukupi.

Toffler dalam Tirtarahardja dan Sula (2000) menganalogikan sekolah dengan sebuah pabrik dimana pendidikan sebagai suatu sistem yang merupakan proses mekanisme bahan mentah (raw input) berupa peserta didik dan setelah melalui tahapan "proses" menghasilkan keluaran (ouput) berupa tamatan/lulusan. Dalam proses dibutuhkan masukan lainya berupa instrumental 
input dan environmental input yang mendukung bagi terjaminnya proses pendidikan (belajarmengajar). Instrumental input meliputi: tenaga guru dan non-guru, kurikulum, anggaran, administrasi, dan prasarana/sarana. Sedangkan environmental input meliputi: sosial budaya, kependudukan, keamanan, politik, ekonomi, dan lain-lain.

Dari sekian banyak komponen input proses belajar mengajar, guru menarik untuk dikaji lebih mendalam. Hal inini dikarenakan guru sebagai agen peubah kognitif, afektif, maupun psikomotorik peserta didik. Soedijarto (1993) mengemukakan bahwa peranan guru sebagai pengelola proses belajar-mengajar sangat menentukan kualitas proses belajar, yang bermuara pada kualitas hasil belajar/mutu pendidikan. Kualitas guru menjadi harga mutlak guna pencapaian pendidikan yang bermutu. Medley dan Shannon seperti dikutip Dunkin (1997) mengemukakan ada tiga aspek kualitas guru yang biasa digunakan dalam menilai kualitas kerja guru, yakni kompetensi guru (teacher effectiveness), kompetensi guru (teacher competence), dan kinerja guru (teacher performance).

Pendapat yang sama dikemukakan Lorin W. Anderson (1989). Anderson menjelaskan bahwa keefektifan guru digunakan untuk merujuk pada hasil kerja yang dicapai guru atau sejumlah kemajuan yang diraih siswa dalam rangka pencapaian tujuan-tujuan khusus pendidikan. Sebagai implikasi atas definisi ini, keefektifan guru hanya dapat dinilai dengan perilaku siswa, dan bukan perilaku guru. Kinerja guru merujuk pada perilaku pada saat mengajar di kelas. Adapun kompetensi guru didefinisikan sebagai seperangkat pengetahuan, kemampuan, dan kepercayaan yang dimiliki seorang guru yang dibawa dalam situasi mengajar. Kompetensi guru (teacher competence) merupakan salah satu aspek penting bagi guru dalam mengajar. Bahkan Anderson mengemukakan bahwa kompetensi dapat digunakan untuk mempertimbangkan guru yang efektif.

Pengertian ini mengandung makna bahwa kompetensi bersifat kompleks dan merupakan satu kesatuan yang utuh yang menggambarkan potensi, pengetahuan, keterampilan, sikap dan nilai, yang dimiliki seseorang yang terkait dengan profesi tertentu dan berkenaan dengan bagianbagian yang dapat diaktualisasikan dalam bentuk tindakan atau kinerja untuk menjalankan profesi tersebut. Sedangkan bentuk dan kualitas kinerja dapat dipengaruhi oleh faktor eksternal antara lain lingkungan atau iklim kerja dan tantangan atau tuntutan pekerjaan. Oleh karena itu, kualifikasi dan profesionalitas merupakan suatu contoh dari perwujudan kompetensi yang dimiliki seseorang. Kompetensi terdiri dari pengetahuan dan keterampilan yang secara spesifik terstandar dan diterapkan dalam melakukan pekerjaan sesuai dengan persyaratan yang telah ditentukan.

Pemerintah Indonesia telah mengembangkan "Sepuluh Kompetensi Guru" pada tahun 1980 yang harus dipunyai guru yang profesional, yaitu: kemampuan menguasai bahan, kemampuan mengelola program belajar mengajar, kemampuan mengelola kelas, kemampuan menggunakan media/sumber, kemampuan menguasai landasanlandasan kependidikan, kemampuan mengelola interaksi belajar-mengajar, kemampuan menilai prestasi peserta didik untuk kepentingan pengajaran, kemampuan mengenal fungsi dan program bimbingan dan penyuluhan, kemampuan mengenal dan menyelenggarakan administrasi sekolah, dan kemampuan memahami prinsipprinsip dan menafsirkan hasil-hasil penelitian pendidikan guna keperluan pengajaran (Samana, 1994).

Selanjutnya, berdasarkan Undang-Undang RI Nomor 14 tahun 2005 Tentang Guru dan Dosen dikatakan bahwa seorang guru wajib memiliki kualifikasi akademik, kompetensi, sertifikat pendidik, sehat jasmani dan rohani, serta memiliki kemampuan untuk mewujudkan tujuan pendidikan nasional. Dalam hal ini Kompetensi yang dimaksud adalah meliputi kompetensi pedagogik, kompetensi kepribadian, kompetensi sosial dan kompetensi profesional. Ke empat kompetensi tersebut harus dimiliki seorang pendidik sesuai atau melebihi standar nasioal baru dapat dikatakan guru tersebut guru profesional.

Kompetensi profesional adalah kemampuan penguasaan materi pembelajaran secara luas dan mendalam yang memungkinkannya membimbing peserta didik memenuhi standar kompetensi yang ditetapkan dalam standar nasional pendidikan. Kompetensi pedagogik 
adalah kemampuan mengelola pembelajaran peserta didik yang meliputi pemahaman terhadap peserta didik, perancangan dan dan pelaksanaan pembelajaran peserta didik, evaluasi hasil belajar, dan pengembangan peserta didik untuk mengaktualisasikan sebagai potensi yang dimilikinya. Kompetensi kepribadian adalah kemampuan diri yang mantap, stabil, dewasa, arif dan wibawa, menjadi teladan peserta didik, dan berakhlak mulia. Sedangkan kompetensi sosial adalah kemampuan mendidik sebagai bagian dari masyarakat untuk berkomunikasi dan bergaul secara efektif dengan peserta didik, sesama pendidik, tenaga kependidikan, orangtua/wali peserta didik, dan masyarakat sekitar.

Ke-empat standar kompetensi tersebut mencerminkan empat standar kompetensi guru yang masih bersifat umum dan perlu dijabarkan ke dalam perangkat kompetensi dan subkompetensi yang dikemas secara koheren dan sistematis dengan menempatkan manusia sebagai makhluk ciptaan Tuhan Yang Maha Esa yang beriman dan bertaqwa, dan sebagai warganegara Indonesia yang demokratis dan bertanggung jawab. Penjabaran lebih lanjut mengenai kompetensi guru ini dapat dilihat dalam Permendiknas Nomor 16 tahun 2007 tentang Standar Akademik dan Kompetensi Guru.

Standar kompetensi guru bertujuan untuk memperoleh acuan baku dalam pengukuran kinerja guru untuk mendapatkan jaminan kualitas guru dalam meningkatkan kualitas proses pembelajaran. Standar kompetensi guru berfungsi sebagai tolok ukur semua pihak yang berkepentingan di bidang pendidikan dalam rangka pembinaan, peningkatan kualitas dan penjenjangan karir guru, dan meningkatkan kinerja guru dalam bentuk kreativitas, inovasi, keterampilan, kemandirian, dan tanggung jawab sesuai dengan jabatan profesional.

\section{Metode Penelitian}

Lingkup kegiatan evaluasi ini secara kelembagaan meliputi sekolah dan madrasah di jenjang pendidikan dasar dan menengah, baik sekolah yang berstatus negeri maupun sekolah swasta. Hal ini berarti seluruh sekolah di Bontang yang terdiri atas 53 SD/MI, 30 SLTP/Mts dan 16 SMA/ SMK/MA akan dicakup dalam studi pendahuluan ini. Adapun substansi yang diteliti meliputi karakteristik guru dan kompetensi guru dalam belajar mengajar, pembinaan guru, dukungan sumber belajar, dan kebutuhan guru akan pelatihan.

Populasi studi ini adalah semua guru pada jenjang SD/MI, SMP/MTs, dan SMA/SMK/MA, baik negeri maupun swasta di Kota Bontang. Berdasarkan data statistik jumlah seluruh guru adalah 1.782. Namun pada saat pengumpulan data, ternyata sejumlah guru bekerja rangkap di beberapa sekolah. Dalam kasus demikian, pengumpulan data hanya dilakukan satu kali saja pada seorang responden guru, sehingga jumlah seluruh guru yang menjadi responden penelitian ini adalah 1.267 orang, terdiri atas 623 guru SD/ MI, 347 SMP/MTs, dan 297 SMA/SMK/MA.

Terdapat dua jenis pengumpulan data yang akan digunakan yaitu kuesioner dan dokumentasi. Kuesioner digunakan dengan subyek guru digunakan untuk melihat variabel kompetensi mengajar guru. Studi dokumen dipusatkan pada dokumen perencanaan tingkat sekolah. Data yang digali dari dokumen-dokumen ini adalah prioritas pembangunan pendidikan dan hasil pelaksanaan program pembangunan pendidikan. Data guru dianalisis secara statistik deskriptif dengan melihat rerata maupun sebaran, serta dilakukan analisis statistik inferensial sederhana.

\section{Hasil Penelitian dan Pembahasan}

Pada hasil penelitian yang didasarkan pada data yang diperoleh dari seluruh guru jenjang pendidikan dasar dan menengah, sekolah negeri maupun sekolah swasta. Aspek yang dikaji adalah kompetensi mengajar guru dan kebutuhan guru akan pelatihan.

\section{Kompetensi Mengajar Guru}

Dalam kajian ini kompetensi mengajar guru mencakup dua hal yaitu penguasaan guru atas materi pelajaran dan kesesuaian mengajar. Kompetensi guru diantaranya dilihat dari penguasaan guru atas materi pelajaran yang menjadi tanggung jawabnya. Tabel 1 memperlihatkan bahwa guru SD/MI pada umumnya hanya menguasai sekitar separuh materi mata pelajaran yang menjadi tanggung jawabnya. Guru paling banyak menguasai mata pelajaran adalah guru 
kelas 1 SD/MI yang menguasai 59,5\% materi pelajaran, sedangkan guru paling tidak menguasai adalah guru kelas 5 SD/MI yang hanya menguasai $49 \%$ materi pelajaran.

Tabel 1. Rerata Penguasaan Materi Mata Pelajaran oleh Guru SD/MI terhadap Mata Pelajaran yang Menjadi Tanggungjawab Utamanya Berdasarkan Kelas yang Diajar

\begin{tabular}{|l|c|c|}
\hline \multicolumn{1}{|c|}{ Kelas yang diajar } & F & $\begin{array}{c}\text { Rerata } \\
(\%)\end{array}$ \\
\hline 1. Kelas 1 & 59 & 59,5 \\
\hline 2. Kelas 2 & 54 & 55,9 \\
\hline 3. Kelas 3 & 63 & 51,2 \\
\hline 4. Kelas 4 & 51 & 50,6 \\
\hline 5. Kelas 5 & 55 & 49,0 \\
\hline 6. Kelas 6 & 69 & 51,4 \\
\hline
\end{tabular}

Pada jenjang SMP/MTs dan SMA/SMK/MA, hasil penelitian mengungkapkan bahwa guru-guru di jenjang pendidikan tersebut menguasai sebagian besar materi mata pelajaran yang diajarkannya kepada peserta didik. Rerata materi yang dikuasai guru berkisar antara $78,9 \%$ sampai $85,7 \%$. Bila dilihat menurut kelas, tidak ada perbedaan berarti penguasaan materi mata pelajaran guru pada kelas 1 , kelas 2, dan kelas 3. Rerata penguasaan guru atas materi pelajaran relatif sama besar, yaitu berkisar antara $84,4 \%$ sampai $85 \%$.
Dalam pada itu, Tabel 2 mengungkapkan penguasaan guru SMP dan SMA/SMK/MA atas materi mata pelajaran berdasarkan mata pelajaran yang menjadi tanggung jawab utamanya. Dengan menggunakan kriteria proporsi penguasaan materi yang ditetapkan, maka tampak ada lima mata pelajaran yang dikuasai guru dengan "sangat baik" (di atas 85\%), yaitu mata pelajaran Matematika, Bahasa Inggris, Biologi, Elektronik, dan Kewarganegaraan. Lima materi mata pelajaran lainnya yang dengan "baik" $(83 \%-<85 \%)$ dikuasai guru adalah Bahasa Indonesia, Ekonomi, Agama, Pendidikan Jasmani, dan Seni. Selanjutnya, guru yang tergolong "cukup" dan "kurang baik" dalam menguasai materi mata pelajaran adalah pada mata pelajaran Kimia, Fisika, dan Sejarah (80\%-<83\%), serta mata pelajaran Geografi, Otomotif, dan Sosiologi (kurang dari $80 \%$ ).

Idealnya seorang guru mengajar mata pelajaran yang sesuai dengan latar belakang pendidikannya. Dengan latar belakang pendidikan guru yang sesuai dengan mata pelajaran yang diajarkan, guru bersangkutan diharapkan dapat mentransformasikan ilmu pengetahuannya kepada peserta didik secara optimal. Tabel 3 menunjukkan sebesar $67,5 \%$ guru SMP/MTs dan SMA/SMK/MA memiliki kesesuaian antara latar belakang

Tabel 2. Rerata Penguasaan Materi Mata Pelajaran oleh Guru SMP dan SM terhadap Mata Pelajaran yang Menjadi Tanggung jawab Utamanya Berdasarkan Mata Pelajaran

\begin{tabular}{|c|c|c|}
\hline Mata Pelajaran yang Diajar & $\mathrm{F}$ & Rerata (\%) \\
\hline 1. Ekonomi & 22 & 84,9 \\
\hline 2. Kimia & 17 & 80,0 \\
\hline 3. Agama & 57 & 84,2 \\
\hline 4. Bhs Inggris & 53 & 86,2 \\
\hline 5. Fisika & 30 & 82,7 \\
\hline 6. Pend Jasmani & 26 & 83,8 \\
\hline 7. Seni & 12 & 84,6 \\
\hline 8. Sejarah & 25 & 81,5 \\
\hline 9. Bhs Indonesia & 46 & 84,1 \\
\hline 10. Geografi & 17 & 78,7 \\
\hline 11. Sosiologi & 8 & 76,9 \\
\hline 12. Kewarganegaraan & 33 & 86,0 \\
\hline 13. Matematika & 58 & 85,0 \\
\hline 14. Biologi & 34 & 85,2 \\
\hline 15. Otomotif & 6 & 79,2 \\
\hline 16. Elektronik & 2 & 85,0 \\
\hline
\end{tabular}
Keterangan:
1. Sangat baik $=85 \%-<87 \%$
3. Cukup $=80 \%-<83 \%$
2. Baik $=83 \%-<85 \%$
4. Kurang baik $=<80 \%$ 
pendidikan yang dimilikinya dengan mata pelajaran utama yang diajarkan. Sebagai gambaran, apabila seorang guru adalah seorang sarjana Matematika, maka guru tersebut utamanya ditugaskan mengajar mata pelajaran Matematika pula.

Meskipun begitu, masih ada sebesar 23,1\% guru SMP/MTs dan SMA/SMK/MA di kota Bontang yang tergolong "kurang sesuai" antara latar belakang pendidikan dengan mata pelajaran yang ditugaskan kepada mereka. Bahkan, 9\% guru "tidak sesuai" penugasan mengajarnya, misalnya guru dengan latar belakang pendidikan BP mengajar mata pelajaran Fisika. Guru bersangkutan tentunya tidak memiliki kompetensi untuk mengajar mata pelajaran tersebut, yang pada gilirannya berdampak negatif atas mutu proses dan hasil belajar siswa.

Tabel 3. Kesesuaian Latar Belakang Pendidikan Guru SMP/MTs dan SM dengan Mata Pelajaran Utama yang Diajarkan

\begin{tabular}{|l|c|c|}
\hline Tingkat Kesesuaian & $\mathrm{F}$ & $\%$ \\
\hline 1. Sesuai & 377 & 67,5 \\
\hline 2. Kurang sesuai & 128 & 23,1 \\
\hline 3. Tidak sesuai & 50 & 9,0 \\
\hline \multicolumn{1}{|c|}{ Jumlah } & 555 & 100 \\
\hline
\end{tabular}

Keterangan:

1. Sesuai: Latar belakang pendidikan sama dengan matapelajaran yang diajarkan

2. Kurang Sesuai: Latar belakang pendidikan berada satu rumpun ilmu dengan mata pelajaran yang diajarkan, misalnya Biologi dengan Fisika, IPS dengan Sejarah

3. Tidak Sesuai: Latar belakang pendidikan tidak satu rumpun dengan mata pelajaran yang diajarkan, misalnya Matematika dengan Pendidikan Jasmani.

Selanjutnya, setelah dianalisis lebih jauh berdasarkan jenis sekolahnya, SMA dan MA merupakan sekolah dengan guru yang proporsinya paling banyak memiliki kesesuaian antara latar belakang pendidikan dengan mata pelajaran utama yang diajarkannya, yaitu $87,5 \%$ dan $86,7 \%$ bila dibandingkan dengan dengan jenis sekolah lainnya. Sementara kategori "kurang sesuai" lebih besar proporsinya ditemui pada SMP $(27,7 \%)$ dan SMK (29,0\%). Tabel 4 menunjukkan bahwa guru yang paling banyak "tidak sesuai" mata pelajaran yang diajarkan dengan latar belakang pendidikan yang dimilikinya adalah MTs, yaitu sebesar 38,7\% bila dibandingkan dengan SMP $(9,9 \%)$, SMA $(2,3 \%)$, MA $(6,7 \%)$, dan SMK $(6,5 \%)$.

Tabel 4. Kesesuaian Latar Belakang Pendidikan Guru SMP/MTs dan SM dengan

Mata Pelajaran Utama yang Diajarkan Berdasarkan Jenis Sekolah

\begin{tabular}{|l|c|c|c|c|c|}
\hline $\begin{array}{c}\text { Tingkat } \\
\text { kesesuaian }\end{array}$ & SMP & MTs & SMA & MA & SMK \\
\hline 1. Sesuai & $62,4 \%$ & $38,7 \%$ & $87,5 \%$ & $86,7 \%$ & $64,5 \%$ \\
& $(171)$ & $(12)$ & $(112)$ & $(13)$ & $(69)$ \\
\hline 2. Kurang & $27,7 \%$ & $22,6 \%$ & $10,2 \%$ & $6,7 \%$ & $29,0 \%$ \\
sesuai & $(76)$ & $(7)$ & $(13)$ & $(1)$ & $(31)$ \\
\hline 3. Tidak sesuai & $9,9 \%$ & $38,7 \%$ & $2,3 \%$ & $6,7 \%$ & $6,5 \%$ \\
& $(27)$ & $(12)$ & $(3)$ & $(1)$ & $(7)$ \\
\hline Jumlah & $100 \%$ & $100 \%$ & $100 \%$ & $100 \%$ & $100 \%$ \\
& $(274)$ & $(31)$ & $(128)$ & $(15)$ & $(107)$ \\
\hline
\end{tabular}

\section{Kebutuhan Guru akan Pelatihan}

Upaya untuk meningkatkan profesionalisme guru dilakukan melalui kegiatan pelatihan. Namun berdasarkan Ternyata, masih cukup banyak guru yang tidak pernah mengikuti penataran/pelatihan $(43,0 \%)$. Berdasarkan Tabel 5, pelatihan "Penggunaan Metode Belajar Mengajar" cenderung dibutuhkan hampir oleh semua guru, baik oleh guru di sekolah negeri maupun swasta. MTs dan MA tampak lebih membutuhkan materi pelatihan ini. Ini tercermin dengan tanggapan mereka yang $100 \%$ memilih "dibutuhkan." Sedangkan di MI hanya sekitar $6.8 \%$ guru yang tidak membutuhkan dan kurang membutuhkan, dan merupakan jenis sekolah yang paling sedikit gurunya memilih "dibutuhkan" dibandingkan jenis sekolah lainnya.

Menurut latar belakang pendidikan dan status kepegawaian, guru yang berlatar belakang pendidikan non-keguruan cenderung membutuhkan pelatihan "Penggunaan Metode Belajar Mengajar," baik diploma maupun S1. Hal ini terlihat dari jawaban mereka yang tidak memilih "tidak dibutuhkan" sama sekali. Untuk guru berpendidikan S2, biarpun yang menjawab "kurang membutuhkan" relatif banyak, namun banyak pula yang membutuhkan pelatihan $(85,7 \%)$. Sementara guru honor terlihat lebih banyak yang membutuhkan pelatihan "Penggunaan Metode Belajar Mengajar" ini. 
Tabel 5. Tanggapan Guru tentang "Pelatihan untuk Meningkatkan Kemampuan Guru dalam Menggunakan Metode Belajar Mengajar"

\begin{tabular}{|c|c|c|c|c|c|}
\hline \multirow{2}{*}{ No } & \multirow{2}{*}{$\begin{array}{l}\text { Status } \\
\text { Sekolah }\end{array}$} & \multicolumn{3}{|c|}{$\begin{array}{c}\text { Kebutuhan Guru akan Pelatihan } \\
\text { Metode Belajar Mengajar }\end{array}$} & \multirow{2}{*}{$\mathrm{F}$} \\
\hline & & $\begin{array}{c}\text { Tidak } \\
\text { dibutuhkan }\end{array}$ & $\begin{array}{c}\text { Kurang } \\
\text { dibutuhkan }\end{array}$ & Dibutuhkan & \\
\hline 1 & Negeri & 1.0 & 1.2 & 97.8 & 593 \\
\hline \multirow[t]{3}{*}{2} & Swasta & 0.8 & 1.7 & 97.8 & 593 \\
\hline & Total & 0.8 & 1.7 & 97.8 & 1186 \\
\hline & $\begin{array}{l}\text { Jenjang } \\
\text { Pendidikan }\end{array}$ & & & & \\
\hline 1 & $\begin{array}{l}\text { Sekolah } \\
\text { Menengah }\end{array}$ & 0.6 & 1.2 & 98.2 & 167 \\
\hline 2 & $\begin{array}{l}\text { Diploma } \\
\text { Keguruan }\end{array}$ & 0.6 & 0.6 & 98.8 & 339 \\
\hline 3 & $\begin{array}{l}\text { Diploma Non- } \\
\text { keguruan }\end{array}$ & 0.0 & 2.1 & 97.9 & 47 \\
\hline 4 & S1 Keguruan & 1.2 & 1.4 & 97.5 & 432 \\
\hline 5 & $\begin{array}{l}\text { S1 Non- } \\
\text { keguruan }\end{array}$ & 0.0 & 2.3 & 97.7 & 172 \\
\hline \multirow[t]{3}{*}{6} & $\mathrm{~S} 2$ & 0.0 & 14.3 & 85.7 & 7 \\
\hline & Total & 0.7 & 1.4 & 97.9 & 1164 \\
\hline & Jenis Sekolah & & & & \\
\hline 1 & SD & 0.5 & 0.5 & 98.9 & 566 \\
\hline 2 & MI & 3.4 & 3.4 & 93.1 & 29 \\
\hline 3 & SMP & 0.7 & 1.4 & 98.0 & 294 \\
\hline 4 & MTs & 0.0 & 0.0 & 100.0 & 35 \\
\hline 5 & SMA & 0.8 & 4.5 & 94.7 & 132 \\
\hline 6 & MA & 0.0 & 0.0 & 100.0 & 13 \\
\hline \multirow[t]{3}{*}{7} & SMK & 1.7 & 2.6 & 95.7 & 116 \\
\hline & Total & 0.8 & 1.4 & 97.8 & 1185 \\
\hline & $\begin{array}{l}\text { Status Kepe- } \\
\text { gawaian Guru }\end{array}$ & & & & \\
\hline 1 & Guru PNS & 1.2 & 1.0 & 97.8 & 415 \\
\hline 2 & Guru Honor & 0.8 & 1.2 & 98.0 & 256 \\
\hline 3 & $\begin{array}{l}\text { Guru Tetap } \\
\text { Yayasan }\end{array}$ & 0.3 & 1.8 & 97.8 & 325 \\
\hline 4 & $\begin{array}{l}\text { Guru Tidak } \\
\text { Tetap Yayasan }\end{array}$ & 0.6 & 2.2 & 97.2 & 179 \\
\hline 5 & Lainnya & 0.0 & 0.0 & 100.0 & 3 \\
\hline & Total & 0.8 & 1.4 & 97.8 & 1178 \\
\hline
\end{tabular}

Tabel 6. Tanggapan Guru tentang "Pelatihan Manajemen Pengelolaan Kelas"

\begin{tabular}{|c|c|c|c|c|c|}
\hline \multirow{2}{*}{ No } & \multirow{2}{*}{ Status Sekolah } & \multicolumn{3}{|c|}{$\begin{array}{c}\text { Kebutuhan Guru akan Pelatihan } \\
\text { Manajemen Pengelolaan Kelas }\end{array}$} & \multirow{2}{*}{$F$} \\
\hline & & $\begin{array}{c}\text { Tidak } \\
\text { dibutuhkan }\end{array}$ & $\begin{array}{c}\text { Kurang } \\
\text { dibutuhkan }\end{array}$ & Dibutuhkan & \\
\hline 1 & Negeri & 1.4 & 4.1 & 94.5 & 581 \\
\hline \multirow[t]{3}{*}{2} & Swasta & 0.3 & 5.9 & 93.8 & 580 \\
\hline & Total & 0.9 & 5.0 & 94.1 & 1161 \\
\hline & Jenjang Pendidikan & & & & \\
\hline 1 & Sekolah Menengah & 1.2 & 0.6 & 98.2 & 165 \\
\hline 2 & Diploma Keguruan & 0.3 & 4.6 & 95.1 & 328 \\
\hline 3 & $\begin{array}{l}\text { Diploma Non- } \\
\text { keguruan }\end{array}$ & 0.0 & 4.5 & 95.5 & 44 \\
\hline 4 & S1 Keguruan & 1.4 & 6.4 & 92.2 & 421 \\
\hline 5 & S1 Non-keguruan & 0.6 & 6.4 & 93.1 & 173 \\
\hline \multirow[t]{3}{*}{6} & S2 & 0.0 & 28.6 & 71.4 & 7 \\
\hline & Total & 0.9 & 5.1 & 94.0 & 1138 \\
\hline & Jenis Sekolah & & & & \\
\hline 1 & SD & 0.7 & 3.8 & 95.5 & 553 \\
\hline 2 & MI & 0.0 & 0.0 & 100.0 & 29 \\
\hline 3 & SMP & 0.3 & 4.5 & 95.1 & 287 \\
\hline 4 & MTs & 0.0 & 0.0 & 100.0 & 32 \\
\hline 5 & SMA & 2.6 & 9.1 & 89.4 & 132 \\
\hline 6 & MA & 0.0 & 0.0 & 100.0 & 13 \\
\hline \multirow[t]{3}{*}{7} & SMK & 2.6 & 10.5 & 86.8 & 114 \\
\hline & Total & 0.9 & 5.0 & 94.1 & 1160 \\
\hline & $\begin{array}{l}\text { Status } \\
\text { Kepegawaian Guru }\end{array}$ & & & & \\
\hline 1 & Guru PNS & 1.0 & 4.7 & 94.3 & 405 \\
\hline 2 & Guru Honor & 1.6 & 2.8 & 95.6 & 251 \\
\hline 3 & $\begin{array}{l}\text { Guru Tetap } \\
\text { Yayasan }\end{array}$ & 0.0 & 6.2 & 93.8 & 321 \\
\hline 4 & $\begin{array}{l}\text { Guru Tidak Tetap } \\
\text { Yayasan }\end{array}$ & 1.1 & 5.1 & 93.7 & 175 \\
\hline 5 & Lainnya & 0.0 & 66.7 & 33.3 & 3 \\
\hline \multicolumn{2}{|r|}{ Total } & 0.9 & 4.9 & 94.2 & 1155 \\
\hline
\end{tabular}

Tabel 7. Tanggapan Guru tentang "Pelatihan untuk Meningkatkan Pengetahuan tentang Materi Mata Pelajaran"

\begin{tabular}{|c|c|c|c|c|c|}
\hline \multirow{2}{*}{ No } & \multirow{2}{*}{ Status Sekolah } & \multicolumn{3}{|c|}{$\begin{array}{c}\text { Kebutuhan Guru akan Pelatihan tentang } \\
\text { Materi Pelajaran }\end{array}$} & \multirow{2}{*}{$\mathrm{F}$} \\
\hline & & $\begin{array}{c}\text { Tidak } \\
\text { dibutuhkan }\end{array}$ & $\begin{array}{c}\text { Kurang } \\
\text { dibutuhkan }\end{array}$ & Dibutuhkan & \\
\hline 1 & Negeri & 1.2 & 0.8 & 98.0 & 592 \\
\hline \multirow[t]{3}{*}{2} & Swasta & 0.5 & 4.4 & 95.1 & 580 \\
\hline & Total & 0.8 & 2.6 & 96.5 & 1178 \\
\hline & Jenjang Pendidikan & & & & \\
\hline 1 & Sekolah Menengah & 0.6 & 1.2 & 98.2 & 165 \\
\hline 2 & Diploma Keguruan & 0.0 & 1.2 & 98.8 & 328 \\
\hline 3 & $\begin{array}{l}\text { Diploma } \\
\text { Nonkeguruan }\end{array}$ & 0.0 & 2.2 & 97.8 & 44 \\
\hline 4 & S1 Keguruan & 1.4 & 3.5 & 95.1 & 421 \\
\hline 5 & S1 Nonkeguruan & 1.7 & 4.6 & 93.6 & 173 \\
\hline \multirow[t]{3}{*}{6} & S2 & 0.0 & 14.3 & 85.7 & 7 \\
\hline & Total & 0.9 & 2.7 & 96.5 & 1156 \\
\hline & Jenis Sekolah & & & & \\
\hline 1 & SD & 0.4 & 1.6 & 98.0 & 560 \\
\hline 2 & MI & 0.0 & 0.0 & 100.0 & 27 \\
\hline 3 & SMP & 0.7 & 3.4 & 95.9 & 290 \\
\hline 4 & MTs & 0.0 & 2.9 & 97.1 & 34 \\
\hline 5 & SMA & 2.2 & 7.5 & 90.3 & 134 \\
\hline 6 & MA & 0.0 & 0.0 & 100.0 & 14 \\
\hline \multirow[t]{3}{*}{7} & SMK & 2.5 & 0.85 & 96.6 & 118 \\
\hline & Total & 0.8 & 2.6 & 96.5 & 1177 \\
\hline & $\begin{array}{l}\text { Status } \\
\text { Kepegawaian Guru }\end{array}$ & & & & \\
\hline 1 & Guru PNS & 1.2 & 1.0 & 97.8 & 405 \\
\hline 2 & Guru Honor & 0.4 & 2.8 & 96.8 & 251 \\
\hline 3 & $\begin{array}{l}\text { Guru Tetap } \\
\text { Yayasan }\end{array}$ & 0.3 & 4.7 & 95.0 & 321 \\
\hline 4 & $\begin{array}{l}\text { Guru Tidak Tetap } \\
\text { Yayasan }\end{array}$ & 1.7 & 2.8 & 95.5 & 175 \\
\hline 5 & Lainnya & 0.0 & 0.0 & 100.0 & 3 \\
\hline \multicolumn{2}{|r|}{ Total } & 0.9 & 2.6 & 96.5 & 1171 \\
\hline
\end{tabular}

Tabel 6 memperlihatkan bahwa pelatihan "Manajemen Pengelolaan Kelas" cenderung dibutuhkan hampir oleh semua guru, baik oleh guru di sekolah negeri maupun swasta. Seluruh guru MI, MTs dan MA tampak lebih membutuhkan materi pelatihan ini. Hal ini tercermin dengan tanggapan mereka yang $100 \%$ memilih pelatihan tersebut "dibutuhkan," yang mengindikasikan adanya "masalah" pengelolaan kelas di ketiga jenis sekolah tersebut.

Menurut latar belakang pendidikan, hampir semua guru cenderung membutukan pelatihan "Manajemen Pengelolaan Kelas." Namun guru berlatar belakang pendidikan S2 yang membutuhkan pelatihan ini tidak sebanyak guru dengan latar belakang pendidikan lainnya. Sedangkan menurut status kepegawaian, hampir semua guru membutuhkan pelatihan "Manajemen Pengelolaan Kelas," terutama bagi guru yang berstatus honor.

Dari Tabel 7 diketahui bahwa pelatihan "Peningkatan Pengetahuan tentang Materi Mata Pelajaran" cenderung dibutuhkan hampir oleh semua guru. Namun guru di sekolah negeri $(98 \%)$ 
cenderung lebih banyak yang membutuhkan dibandingkan dengan di sekolah swasta (95,1\%). Kemudian, MI dan MA tampak lebih membutuhkan materi pelatihan ini. Hal ini tercermin dengan tanggapan mereka yang $100 \%$ memilih pelatihan ini "dibutuhkan." Sementara di MTs hanya sekitar $97,1 \%$ guru yang membutuhkan materi ini. Sedangkan guru SMA terlihat lebih sedikit yang membutuhkan pelatihan "Peningkatan Pengetahuan tentang Materi Mata Pelajaran (90,3\%)."

Menurut latar belakang pendidikan, hampir semua guru cenderung membutuhkan pelatihan "Peningkatan Pengetahuan tentang Materi Mata Pelajaran." Namun guru berlatar belakang Diploma, baik keguruan maupun non-keguruan terlihat lebih membutuhkan materi pelatihan ini. Sementara guru berpendidikan S2 kurang membutuhkan pelatihan ini, dan hanya sekitar $85.7 \%$ yang membutuhkannya. Sementara menurut status kepegawaian, guru PNS $(97,8 \%)$ dan guru honor $(96,8 \%)$ lebih membutuhkannya pelatihan "Peningkatan Pengetahuan Tentang Materi Mata Pelajaran."

Berdasarkan Tabel 8, pelatihan "Penyusunan Tes" cenderung dibutuhkan hampir oleh semua guru, namun guru di sekolah negeri $(95,6 \%)$ terlihat lebih membutuhkan daripada guru di sekolah swasta $(90,4 \%)$. Guru SMK $(83,6 \%)$ terlihat kurang membutuhkan pelatihan ini, diikuti guru SMA dan SMP. Sedangkan guru SD dan MI "sangat" membutuhkan materi pelatihan ini, yakni ada sekitar 96\% guru memilih "dibutuhkan." Dari tabel yang sama, guru yang berlatar belakang pendidikan S2 $(71,4 \%)$ cenderung kurang membutuhkan pelatihan "Penyusunan Tes," diikuti guru berlatar belakang S1 Non-keguruan (87,2\%). Sementara guru berstatus PNS cenderung lebih membutuhkan pelatihan "Penyusunan Tes" $(96,1 \%)$.

Tabel 8. Tanggapan Guru tentang "Pelatihan untuk Penyusunan Tes"

\begin{tabular}{|c|l|c|c|c|c|}
\hline \multirow{2}{*}{ No } & \multirow{2}{*}{ Status Sekolah } & \multicolumn{3}{|c|}{ Kebutuhan Guru akan Pelatihan tentang } & \multirow{2}{*}{ Penyusunan Tes } \\
\cline { 3 - 5 } & & $\begin{array}{c}\text { Tidak } \\
\text { dibutuhkan }\end{array}$ & $\begin{array}{c}\text { Kurang } \\
\text { dibutuhkan }\end{array}$ & Dibutuhkan & \\
\hline 1 & Negeri & 1.4 & 3.1 & 95.6 & 589 \\
\hline 2 & Swasta Total & 1.2 & 8.6 & 90.4 & 584 \\
\hline & \multicolumn{1}{|c|}{ Total } & 1.2 & 5.8 & 93.0 & 1173 \\
\hline & Jenjang Pendidikan & & & & \\
\hline 1 & Sekolah Menengah & 1.8 & 3.0 & 95.2 & 165 \\
\hline
\end{tabular}

\begin{tabular}{|c|c|c|c|c|c|}
\hline 2 & Diploma Keguruan & 0.3 & 2.7 & 97.0 & 333 \\
\hline 3 & Diploma Non-keguruan & 2.2 & 19.6 & 97.8 & 46 \\
\hline 4 & S1 Keguruan & 1.6 & 5.8 & 92.5 & 428 \\
\hline 5 & S1 Non-keguruan & 1.7 & 11.0 & 87.2 & 172 \\
\hline \multirow[t]{3}{*}{6} & S2 & 0.0 & 28.6 & 71.4 & 7 \\
\hline & Total & 1.3 & 6.0 & 92.7 & 1151 \\
\hline & Jenis Pendidikan & & & & \\
\hline 1 & SD & 0.5 & 3.1 & 96.4 & 556 \\
\hline 2 & MI & 0.0 & 3.4 & 96.6 & 29 \\
\hline 3 & SMP & 1.0 & 8.6 & 90.3 & 290 \\
\hline 4 & MTs & 0.0 & 3.0 & 97.0 & 33 \\
\hline 5 & SMA & 1.5 & 8.2 & 90.3 & 134 \\
\hline 6 & MA & 0.0 & 0.0 & 100.0 & 14 \\
\hline \multirow[t]{3}{*}{7} & SMK & 5.2 & 11.2 & 83.6 & 116 \\
\hline & Total & 1.2 & 5.8 & 93.0 & 1177 \\
\hline & $\begin{array}{l}\text { Status Kepegawaian } \\
\text { Guru }\end{array}$ & & & & \\
\hline 1 & Guru PNS & 1.2 & 2.7 & 96.1 & 411 \\
\hline 2 & Guru Honor & 1.6 & 5.9 & 92.5 & 255 \\
\hline 3 & Guru Tetap Yayasan & 0.6 & 6.3 & 93.1 & 320 \\
\hline 4 & $\begin{array}{l}\text { Guru Tidak Tetap } \\
\text { Yayasan }\end{array}$ & 1.7 & 10.7 & 87.6 & 177 \\
\hline \multirow[t]{2}{*}{5} & Lainnya & 0.0 & 66.7 & 33.3 & 3 \\
\hline & Total & 1.2 & 5.7 & 93.1 & 1166 \\
\hline
\end{tabular}

Tabel 9. Tanggapan Guru tentang "Pelatihan Penguasaan Materi Kurikulum"

\begin{tabular}{|c|c|c|c|c|c|}
\hline \multirow{2}{*}{ No } & \multirow{2}{*}{ Status Sekolah } & \multicolumn{3}{|c|}{$\begin{array}{c}\text { Kebutuhan Guru akan Pelatihan tentang } \\
\text { Penguasaan Materi Kurikulum }\end{array}$} & \multirow{2}{*}{$\mathrm{F}$} \\
\hline & & $\begin{array}{c}\text { Tidak } \\
\text { dibutuhkan }\end{array}$ & $\begin{array}{c}\text { Kurang } \\
\text { dibutuhkan }\end{array}$ & Dibutuhkan & \\
\hline 1 & Negeri & 1.2 & 2.0 & 96.8 & 593 \\
\hline \multirow[t]{3}{*}{2} & Swasta & 0.5 & 5.7 & 93.7 & 574 \\
\hline & Total & 0.9 & 3.9 & 93.0 & 1167 \\
\hline & Jenjang Pendidikan & & & & \\
\hline 1 & Sekolah Menengah & 1.2 & 1.8 & 97.0 & 164 \\
\hline 2 & Diploma Keguruan & 0.0 & 2.4 & 97.6 & 335 \\
\hline 3 & Diploma Non-keguruan & 2.2 & 6.7 & 91.1 & 45 \\
\hline 4 & S1 Keguruan & 1.4 & 4.7 & 93.9 & 428 \\
\hline 5 & S1 Non-keguruan & 0.6 & 5.3 & 94.1 & 169 \\
\hline \multirow[t]{3}{*}{6} & S2 & 0.0 & 28.6 & 71.4 & 7 \\
\hline & Total & 0.9 & 3.9 & 95.2 & 1148 \\
\hline & Jenis Sekolah & & & & \\
\hline 1 & SD & 0.5 & 2.5 & 97.0 & 556 \\
\hline 2 & MI & 0.0 & 3.4 & 96.6 & 29 \\
\hline 3 & SMP & 0.4 & 4.7 & 94.9 & 290 \\
\hline 4 & MTs & 0.0 & 0.0 & 100.0 & 33 \\
\hline 5 & SMA & 1.5 & 5.2 & 93.3 & 134 \\
\hline 6 & MA & 0.0 & 0.0 & 100.0 & 14 \\
\hline \multirow[t]{3}{*}{7} & SMK & 3.5 & 8.7 & 87.8 & 116 \\
\hline & Total & 0.9 & 3.9 & 95.3 & 1166 \\
\hline & $\begin{array}{l}\text { Status Kepegawaian } \\
\text { Guru }\end{array}$ & & & & \\
\hline 1 & Guru PNS & 1.0 & 1.4 & 97.6 & 415 \\
\hline 2 & Guru Honor & 0.8 & 3.5 & 95.7 & 255 \\
\hline 3 & Guru Tetap Yayasan & 0.6 & 6.1 & 93.3 & 313 \\
\hline 4 & $\begin{array}{l}\text { Guru Tidak Tetap } \\
\text { Yayasan }\end{array}$ & 1.1 & 5.7 & 93.1 & 174 \\
\hline 5 & Lainnya & 0.0 & 0.0 & 100.0 & 3 \\
\hline \multicolumn{2}{|r|}{ Total } & 0.9 . & 3.8 & 95.3 & 1160 \\
\hline
\end{tabular}

Tabel 9 memperlihatkan bahwa pelatihan "Penguasaan Materi Kurikulum" dibutuhkan oleh hampir semua guru. Guru di sekolah negeri lebih membutuhkan dibandingkan di sekolah swasta. Guru MTs dan MA tampak lebih membutuhkan materi pelatihan ini. Hal ini tercermin dengan tanggapan mereka yang $100 \%$ memilih pelatihan tersebut "dibutuhkan," sementara di MI hanya sekitar $96.6 \%$ guru yang membutuhkan materi ini. Adapun guru SMK terlihat lebih sedikit yang membutuhkan pelatihan "Penguasaan Materi Kurikulum" dibandingkan jenis sekolah lainnya $(87,8 \%)$.

Guru berlatar belakang Sekolah Menengah (97\%) dan Diploma Keguruan (97,6\%) merupakan guru yang membutuhkan pelatihan "Penguasaan 
Materi Kurikulum." Sedangkan guru berpendidikan S2 kurang membutuhkan pelatihan ini, yaitu hanya sekitar $71,4 \%$ yang memilih bahwa pelatihan tersebut "dibutuhkan." Demikian pula halnya jika guru dilihat menurut status kepegawaian, yakni guru berstatus PNS $(97,6 \%)$ dan guru honor $(95,7 \%)$ lebih membutuhkan pelatihan tentang "Penguasaan Materi Kurikulum" ini.

Upaya peningkatan mutu pendidikan tidak terlepas dari peran guru. Guru merupakan salah satu determinan terhadap peningkatan mutu pendidikan. Penerapan teknologi dalam kegiatan belajar mengajar dianggap sebagai faktor pelengkap (suplementary) terhadap peran guru. Hal ini merupakan suatu justifikasi bahwa dalam kegiatan belajar mengajar peran guru tidak dapat digantikan oleh berbagai sarana bahkan sarana dengan sentuhan teknologi sekalipun. Berdasarkan pada pernyataan tersebut, peningkatan kemampuan guru dapat menjadi jaminan terhadap peningkatan mutu pendidikan.

Guru memang merupakan determinan terhadap peningkatan mutu pendidikan, tetapi tanpa dukungan sarana guru tidak dapat menjalankan perannya dengan efektif. Profesionalisme guru tidak menjadi jaminan bagi hasil kegiatan belajar mengajar maksimal tanpa didukung oleh sumber belajar dan sarana yang memadai. Dalam melaksanakan perannya, guru beranggapan bahwa ketersediaan buku teks sebagai sumber belajar utama dianggap belum memadai. Fakta ini menunjukkan bahwa tanpa dukungan sumber belajar dalam bentuk buku teks, sulit bagi guru untuk dapat meningkatkan prestasi akademis siswa di Kota Bontang. Buku tidak hanya memuat berbagai konsep-konsep yang diajarkan oleh guru; buku juga memuat informasi tambahan yang dapat memberikan ilustrasi bagi siswa untuk memperkaya informasi yang diperoleh dari guru. Argumentasi yang sering dikemukakan terhadap keberadaan buku adalah bahwa fungsi buku teks tidak dapat menggantikan fungsi guru sebagai sumber ilmu.

Dengan demikian fungsi guru adalah sebagai fasilitator siswa. Peran fasilitator yang dimaksud adalah membantu siswa dalam mencari informasi mengerjakan soal atau tugas yang diberikan oleh guru kepada siswa. Pentahapan belajar mengajar tersebut, pada dasarnya tetap memerlukan guru baik sebagai sumber ilmu pengetahuan atau sebagai fasilitator dalam memperdalam ilmu pengetahuan lebih lanjut. Guru memang memegang peran utama dalam mentransfer ilmu pengetahuan kepada siswa, tapi guru bukan satusatunya sumber ilmu pengetahuan.

Kompetensi mengajar guru dilihat dari penguasaan guru atas materi pelajaran yang diajarkan. Kajian ini mengungkapkan penguasaan materi guru SD/MI cukup memprihatinkan, sementara guru SMP/MTs dan SM sudah cukup baik. Demikian juga jika kesesuaian mengajar diukur dengan latar belakang pendidikan dengan mata pelajaran yang diajarkan, maka Kota Bontang tidak harus menjadikan in-service training yang ditujukan untuk meningkatkan kesesuaian latar belakang pendidikan guru dengan mata pelajaran yang diajarkan menjadi prioritas. Sekali lagi, jika program in-service training ini tetap menjadi prioritas maka dalam waktu satu sampai dua tahun seharusnya semua guru dapat ditargetkan. Program pelatihan memang merupakan solusi yang diambil ketika masalah yang timbul adalah berkenaan dengan rendahnya kompetensi. Tetapi pelatihan belum merupakan solusi yang dapat memecahkan masalah ketika suatu organisasi tidak mempunyai visi yang jelas tentang apa yang akan dicapai. Pada dasarnya pelatihan diarahkan untuk memberdayakan tenaga guru untuk mencapai visi sekolah.

Hasil survai menunjukkan bahwa faktor pendidikan dan pengalaman tidak membedakan kebutuhan guru terhadap program-program pelatihan yang diinginkan. Dengan kata lain, guru dengan berbagai jenjang pendidikan dan dengan rentang pengalaman mengajar yang rendah sampai tinggi cenderung membutuhkan program pelatihan. Pemberlakuan kurikulum tingkat satuan pendidikan (KTSP) tidak hanya membawa konsekuensi terhadap metode belajar, cakupan bahan ajar, tetapi juga pada sistem evaluasi. Secara harafiah kompetensi tidak hanya mengukur kemampuan akademis siswa tetapi juga kemampuan dalam mengaplikasikan pengetahuan yang diperoleh dari ruang ke kelas kepada kehidupan sehari-hari sesuai dengan jenjang pendidikan yang ditempuh oleh siswa. 
Berdasarkan pada hasil analisis data survai menunjukkan bahwa guru memerlukan pelatihan manajemen pengelolaan kelas, materi pelajaran, dan penyu-sunan tes. Meskipun hasil survai tidak menanyakan alasan mengapa jenis-jenis pe-latihan tersebut yang diminati, namun penerapan KTSP menjadi alasan yang kuat bagi guru-guru Kota Bontang mengapa programprogram tersebut yang menjadi pilihan. Seperti dikemukakan sebelumnya, perubahan kurikulum membawa konsekuensi terhadap metode mengajar, bahan ajar, serta sistem evaluasi.

\section{Simpulan dan Saran}

\section{Simpulan}

Pengkajian kebutuhan peningkatan kompetensi guru jenjang pendidikan dasar dan menengah di kota Bontang merupakan suatu tahapan untuk mengidentifikasi karakteristik guru dalam upaya meningkatkan mutu pendidikan di kota Bontang melalui penyelenggaraan berbagai program pelatihan. Hasil kajian menunjukkan latar belakang pendidikan guru banyak yang tidak sesuai dengan mata pelajaran yang diajarkan, terutama guru SMP/MTs dan SMA/SMK/MA yang berasal dari sekolah swasta. Hanya dua pertiga guru SMP/MTs dan SMA/SMK/MA tergolong sesuai antara latar belakang pendidikan dengan mata pelajaran yang ditugaskan kepada mereka. Guru yang "kurang sesuai" lebih besar proporsinya ditemui pada SMP dan SMK, sementara guru yang paling banyak "tidak sesuai" (mismatch) adalah MTs.

Kompetensi guru SD/MI pada materi pelajaran yang menjadi tanggung jawabnya masih memprihatinkan. Namun, guru SMP/MTs dan SMA/ SMK/MA sudah menguasai sebagian besar materi mata pelajaran. Ada lima mata pelajaran yang dikuasai guru pada jenjang tersebut dengan "sangat baik" (di atas 85\%), yaitu mata pelajaran Matematika, Bahasa Inggris, Biologi, Elektronik, dan Kewarganegaraan.

Penilaian kebutuhan peningkatan kompetensi guru adalah langkah awal untuk meningkatkan mutu guru. Upaya untuk meningkatkan mutu guru ini telah dilakukan Pemda Bontang melalui berbagai kegiatan pelatihan. Namun, lebih dari dua perlima guru belum pernah mengikuti penataran/pelatihan. Hasil survei menunjukkan pelatihan "Penggunaan Metode Belajar Mengajar," "Manajemen Pengelolaan Kelas," "Peningkatan Pengetahuan tentang Materi Mata Pelajaran," "Penyusunan Tes," dan "Penguasaan Materi Kurikulum" cenderung dibutuhkan hampir oleh semua guru, terutama guru MI, MTs dan MA serta guru yang berlatar belakang pendidikan nonkeguruan. Pelatihan tentang pengembagan kurikulum dan penyusunan tes dibutuhkan hampir oleh semua guru, terutama guru MI, MTs dan MA serta guru yang berlatar belakang pendidikan nonkeguruan.

\section{Saran}

Sebagai titik tolak bagi keberlangsungan kegiatan belajar mengajar di kelas, kurikulum (KTSP) perlu dilakukan sosialisasi, pendampingan/bantuan profesional oleh unit terkait secara terpadu dan bersinergi, baik oleh Balitbang, Ditjen Mandikdasmen, maupun Dinas Pendidikan kota Bontang. Program pelatihan secara spesifik diarahkan untuk meningkatkan kemampuan guru dalam dalam penguasaan KTSP, termasuk di dalamnya adalah landasan filosofinya, metode belajar, dan sistem penilaiannya. Untuk menunjang efektivitas pelaksanaan program pelatihan setiap sekolah perlu untuk menetapkan target yang akan dicapai termasuk kemampuan untuk menyediakan fasilitas pendukung. Hal ini karena arah penerapan KTSP tidak akan diterapkan secara serentak (seragam) tetapi secara bertahap berdasarkan kesiapan sekolah baik kesiapan dalam arti kemampuan menyediakan fasilitas pendidikan, kemampuan guru, dan kondisi social ekonomi lingkungan sekolah.

Meskipun kepala sekolah tidak secara langsung terlibat dalam penerapan KTSP, kepala sekolah mempunyai beberapa peran yang dapat memfasilitasi guru dalam menerapkan KTSP. Atmosfir organisasi sekolah perlu diciptakan bagi guru untuk dapat mengembangkan kemampuan mengajarnya. Penyediaan insentif baik untuk guru maupun siswa dalam rangka penerapan KTSP secara efektif. Oleh karena itu, diperlukan program pelatihan untuk membimbing kepala sekolah mampun menyusun program manajemen pendidikan di tingkat sekolah sehingga dapat memfasilitasi penerapan kurikulum tersebut. 


\section{Pustaka Acuan}

Anderson, Lorin W. 1989. The Effective Teacher Study Guide and Readings. New York: McGraw-Hill, Inc. Dunkin, MJ. 1997. "Assessing Teacher's Effectiveness." Issues in Educational Research, 7(1), 1997, 3751.

Departemen Pendidikan Nasional, 2005. Undang Undang Republik Indonesia Nomor 14 Tahun 2005 Tentang Guru dan Dosen

Peraturan Menteri Pendidikan Nasional, Nomor 16 tahun 2007 Tentang Standar Akademik dan Kompetensi Guru

Samana. 1994. Profesionalisme Keguruan. Yogyakarta: Penerbit Kanisius

Soedijarto. 1993. Memantapkan Sistem Pendidikan Nasional. Jakarta: Grasindo

Tirtarahardja dan Sula. 2000. Pengantar Pendidikan. Jakarta: Rineka Cipta 